\title{
Net Operating Working Capital, Capital Budgeting, And Cash Budgets: A Teaching Example
}

James A Turner, Weber State University, USA

\begin{abstract}
Many introductory finance texts present information on the capital budgeting process, including estimation of project cash flows. Typically, estimation of project cash flows begins with a calculation of net income. Getting from net income to cash flows requires accounting for noncash items such as depreciation. Also important is the effect of changes in net operating working capital on cash flow. While students readily understand how to account for depreciation when calculating cash flow, they typically have much more difficulty understanding how and why changes in working capital affect cash flows. This paper develops a teaching example to show exactly how and why changes in net operating working capital affect cash flows. The example shows how to derive operating cash flows for a proposed project using the accrual accounting method and then shows a cash budget for the same project. Finally, the example shows that the discrepancy between the cash flows shown in the cash budget and the operating cash flows can be resolved by accounting for changes in working capital. A survey of students in an MBA managerial finance course indicates student satisfaction with the teaching example and gives evidence that students prefer the teaching example to explanations of the effect of working capital on project cash flows given in the assigned text.
\end{abstract}

Keywords: Capital Budgeting; Cash Budgets; Working Capital; Cash Flows

\section{INTRODUCTION}

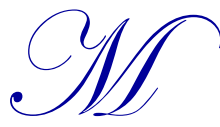

any texts on financial management explain how to track the cash flows associated with a capital investment project. Typically, textbook examples will show forecasted net income from a hypothetical project and then note that depreciation must be added back to net income to obtain "operating cash flow." The examples then show how to account for cash flow from "investments in working capital." While students typically have little trouble understanding how to calculate net income and the rationale for adding back depreciation to obtain operating cash flows, student understanding of cash flows from investment in working capital typically lags much further behind. Moreover, many texts are less than clear in their explanations. This paper provides a teaching example that demonstrates how to determine the levels of working capital for a project and, more importantly, demonstrates exactly how and why changes in levels of working capital correspond to cash flows that must be included in a capital budgeting analysis.

\section{THE TEACHING EXAMPLE}

The teaching example presented here illustrates two methods of tracking the cash flows associated with a capital budgeting problem. The first method, shown in most finance texts, makes use of the principles of accrual accounting, with revenues and costs recognized when they occur, regardless of when the associated cash transactions take place. This method gives the operating cash flow (defined as net income plus depreciation) each

\footnotetext{
${ }^{1}$ See Shapiro (2005, Chapter 3); Ross, Westerfield, Jaffe, and Jordan (2011, Chapter 8); and Brigham and Ehrhardt (2011, Chapter 11) for examples of current textbook treatments of capital budgeting analysis.
} 
period and then tracks the cash flow associated with changes in net operating working capital (defined as current assets minus current liabilities.) The second method tracks actual cash flow through use of a cash budget, which recognizes revenues when cash from sales is received and recognizes costs when cash for materials and other costs is paid. There will, of course, be discrepancies between the operating cash flow shown in the first method and the cash flow shown in the second method, unless the firm operates on a cash-only basis. The discrepancies can be reconciled by noting that changes in levels of working capital are equal to the difference between the operating cash flow and the cash flow shown in the cash budget. The main point of the example is to make explicitly clear to students why working capital must be accounted for in cash budgeting and exactly why and how changes in working capital affect project cash flows.

Suppose a firm is considering the purchase of a machine for $\$ 300,000$. The firm plans to use the machine for four years. Depreciation of the cost of the machine will be straight line for four years. Revenue from the project will be $\$ 200,000$ in Year 1, \$250,000 each in Year 2 and Year 3, and \$200,000 in Year 4. Forecasted production costs will be 50 percent of forecasted sales. For simplicity (but with no loss of generality), assume the machine has no salvage value at the end of the project. The firm's tax rate is $40 \%$.

Table 1 shows the cost of the machine and the forecasted revenue and costs associated with its use, recorded according to the principles of accrual accounting; that is, the revenue from a sale is recorded when the sale is made, not when the cash from the sale is collected, and costs are matched with the product being produced and recorded when the sale is made, not when the costs are actually paid. Table 1 also shows earnings before taxes (EBT), net income, and operating cash flow (OCF). Operating cash flow is defined as net income plus depreciation, as in Shapiro (2005) and Ross, Westerfield, Jaffe, and Jordan (2011). Of course, this "operating cash flow" will not equal true cash flow if there are accounts receivable or accounts payable and if raw materials are sometimes added to inventory after purchase rather than used immediately in production.

Table 1: Net Income Statement and Operating Cash Flows

The table shows the machine cost, the revenues and costs associated with its use, and net income. Depreciation of the cost of the machine is straight line over four years. The tax rate is $40 \%$. Operating cash flows are defined as net income plus depreciation.

\begin{tabular}{|c|c|c|c|c|c|}
\hline & \multicolumn{5}{|c|}{ Year } \\
\hline & $\mathbf{0}$ & 1 & 2 & 3 & 4 \\
\hline Machine Purchase & $(\$ 300,000)$ & & & & \\
\hline Revenue & & $\$ 200,000$ & $\$ 250,000$ & $\$ 250,000$ & $\$ 200,000$ \\
\hline $\begin{array}{l}\text { Costs: } \\
\text { Materials } \\
\text { Labor }\end{array}$ & & $\begin{array}{l}(50,000) \\
(50,000)\end{array}$ & $\begin{array}{l}(62,500) \\
(62,500)\end{array}$ & $\begin{array}{l}(62,500) \\
(62,500)\end{array}$ & $\begin{array}{l}(50,000) \\
(50,000)\end{array}$ \\
\hline Depreciation & & $(75,000)$ & $(75,000)$ & $(75,000)$ & $(75,000)$ \\
\hline EBT & & $\$ 25,000$ & $\$ 50,000$ & $\$ 50,000$ & $\$ 25,000$ \\
\hline Tax & & $(10,000)$ & $(20,000)$ & $(20,000)$ & $(10,000)$ \\
\hline Net Income & & 15,000 & 30,000 & 30,000 & 15,000 \\
\hline OCF & & 90,000 & 105,000 & 105,000 & 90,000 \\
\hline
\end{tabular}

When the firm maintains positive balances in accounts receivable, accounts payable, and inventory, the socalled operating cash flows will not match the actual cash flow. Many finance textbooks that cover the capital budgeting topic either do not make this point explicitly or do not give it much more than a cursory explanation. ${ }^{2}$ Rather than explaining exactly how to reconcile the difference between actual cash flows and operating cash flows, many texts simply note that, along with operating cash flows, it is necessary to account for cash flows that result from changes in working capital. Unfortunately, the connection between cash flows and changes in working capital is often lost on students. To help students better understand the link between working capital and final project cash flows, it is helpful to show exactly how the working capital associated with the proposed project can be forecasted.

\footnotetext{
2 (Ross, et al (2011, p. 243f) and Booth, Cleary, and Drake (2014, p. 674-677) are two of the few texts that give at least some explanation of the link between working capital and cash flows. The Ross, et al explanation is rather brief, but the Booth, et al explanation is quite detailed.
} 


\section{Materials Purchases and Inventory}

To calculate working capital for the present example, suppose that the firm's costs are composed of labor and materials, with equal amounts spent on each. Suppose also that the firm purchases half of the material required for one period's production in the period before production, adding the material purchased to its raw materials inventory for use in the next period. The firm purchases the other half of the materials required for the current period's production at the time of production.

\section{Accounts Receivable and Accounts Payable}

Working capital levels also depend on the firm's collection and payment patterns. Suppose that the firm in the example pays the entirety of its labor costs for a given period during the period when the labor is used. For its materials purchases, suppose the firm pays for 70 percent of the material it purchases during the purchase period and pays the remaining 30 percent the following period. The firm collects the cash for 50 percent of its sales during the period the sale is made and collects the remaining 50 percent the following period. Suppose finally that the firm maintains a $\$ 20,000$ average cash balance during the life of the project, returning the cash for general use at the end of the project's life.

Given the firm's revenues, costs and payment patterns, it is possible to forecast the firm's current assets, current liabilities, and working capital balance, which are shown in Table 2. For example, the firm's inventory balance at Year 0 is $\$ 25,000$, which represents half of the $\$ 50,000$ inventory the firm will require for production in Year 1. In Year 1, the firm uses its inventory purchased in Year 0 and also purchases half the amount of materials required in Year 2, resulting in an inventory balance of $\$ 62,500 / 2=\$ 31,250$ at the end of Year 1 . Since the firm collects only half its revenue in the period of sale, the accounts receivable balance is $\$ 200,000 / 2=\$ 100,000$ at the end of Year 1 and $\$ 250,000 / 2=\$ 125,000$ at the end of Year 2. The firm pays for 70 percent of its purchases during the period of purchase, so its accounts receivable balance for the $\$ 25,000$ of inventory it purchased in Year 0 is $\$ 25,000(1-0.7)=\$ 7,500$. In Year 1 , its accounts payable balance is 30 percent of the sum of the materials purchased in Year 1 for use in Year 1 and the materials purchased in Year 1 for use in Year 2, or $[\$ 25,000+$ $\$ 31,250](0.3)=\$ 16,875$. Inventory, accounts receivable, and accounts payable balances for other years can be calculated similarly.

Table 2: Net Operating Working Capital and Cash Flow

The table shows each component of net operating working capital for each period of the project's life, as well as the changes in working capital and the cash flow from changes in working capital. Once the project ends, working capital is recovered completely.

\begin{tabular}{|l|c|c|c|c|c|}
\hline \multirow{2}{*}{ Cash } & \multicolumn{5}{|c|}{ Year } \\
\cline { 2 - 6 } & $\mathbf{0}$ & $\mathbf{1}$ & $\mathbf{2}$ & $\mathbf{3}$ & $\mathbf{4}$ \\
\hline Inventory & $\$ 20,000$ & $\$ 20,000$ & $\$ 20,000$ & $\$ 20,000$ & $\$ 0$ \\
\hline Accounts Receivable & 25,000 & 31,250 & 31,250 & 25,000 & 0 \\
\hline Accounts Payable & 0 & 100,000 & 125,000 & 125,000 & 0 \\
\hline NOWC & 7,500 & $\$ 16,875$ & 18,750 & 16,875 & 0 \\
\hline Changes in NOWC & 37,500 & 134,375 & 157,500 & 153,125 & $(153,125)$ \\
\hline Cash flow from changes in NOWC & 37,500 & 96,875 & 23,125 & $(4,375)$ & $(15)$ \\
\hline
\end{tabular}

\section{Cash Flows from Changes in Working Capital}

Table 2 also shows cash flows from changes in working capital levels. Increases in working capital correspond with negative cash flows, as more cash is required to achieve the higher level of working capital, while decreases in working capital correspond with positive cash flows. The cash flows from changes in working capital are combined with the operating cash flows to obtain the final cash flows from the project. Using these total cash flows (shown in Table 3), one can calculate the project's net present value, internal rate of return, or any other metrics used to decide the project's feasibility. 
Table 3: Project Cash Flows

The table shows project cash flows, which in Year 0 consist of the sum of the cash flow from purchase of the machine in other years, consisting of the sum of operating cash flows and cash flows from changes in net operating working capital.

\begin{tabular}{|c|c|c|c|c|c|}
\hline & \multicolumn{5}{|c|}{ Year } \\
\hline & $\mathbf{0}$ & 1 & 2 & 3 & 4 \\
\hline Machine Cost & $(\$ 300,000)$ & & & & \\
\hline OCF & & $\$ 90,000$ & $\$ 105,000$ & $\$ 105,000$ & $\$ 90,000$ \\
\hline Cash flow from changes in NOWC & $(37,500)$ & $(96,875)$ & $(23,125)$ & 4,375 & 153,125 \\
\hline Net Project Cash Flows & $(337,500)$ & $(6,875)$ & 81,875 & 109,375 & 243,125 \\
\hline
\end{tabular}

\section{Student Understanding of Cash Flow from Changes in Working Capital}

Most students seem to understand easily that because depreciation was deducted in the calculation of net income, net income is not cash flow, so students seldom misunderstand the rationale for calculating operating cash flows by adding depreciation to net income. Students typically have much more trouble understanding how and why to calculate cash flows from changes in working capital, however. A question received by email in February 2013 from a student in an undergraduate capital budgeting class is typical:

Professor, could you please explain how the new working capital is added or subtracted from the cash flow? I've been trying the last couple days to figure [it] out. I am just lost on it. Is it added to the operating cash flow?

While most students are eventually able to make the working capital cash flow calculation by simply memorizing the method of tracking changes in working capital, many do not readily understand why changes in working capital represent cash flows (and most textbooks do not clear up the confusion, sometimes only noting that increases in working capital are a use of cash and that decreases in working capital are a source of cash.)

Students will understand project cash flows better if they see exactly how changes in working capital correspond to cash flows, rather than simply memorize the mechanics of calculating cash flows from working capital by taking the difference between working capital from one period to the next, altering the sign of the result, and labeling the result as cash flows from changes in working capital. One way of making the concept of cash flows from changes in working capital much more clear for students would be to develop a cash budget for the hypothetical project, which would keep track of cash payments and disbursements rather than accounting for net income through accrual accounting methods. There will, of course, be a discrepancy between operating cash flow and the cash flows shown in the cash budget. The amount of the discrepancy will exactly equal the cash flow from changes in working capital and students will then see exactly how changes in working capital correspond to cash flows and how to reconcile the difference between operating cash flows and the final project cash flows shown in the cash budget.

\section{The Cash Budget}

In the current example, given the firm's collection and payment patters, its cash budget would be as shown in the Table 4. For Year 0, actual project cash flows are negative $\$ 337,500$, which is $\$ 37,500$ lower than the $\$ 300,000$ negative cash flow from the machine cost. For Year 1, operating cash flows are $\$ 90,000$, while actual project cash flows are negative $\$ 6,875$, for a difference of $\$ 96,865$. Table 5 shows the differences between the machine costs in Year 0 and the cash flows from the cash budget in Year 0 and the differences between the operating cash flows and the cash flows from the cash budget for the other years. Note that the differences between the operating cash flows and the actual project cash flows for each year exactly equal the changes in working capital for each year shown in Table 2. 
Table 4: Cash Budget, Collections, Payments, and Cash Flow

The table shows the cash budget for the project. Total sales are shown along with collections in each year, assuming the firm collects $50 \%$ of a given year's sales in the same year and the remaining 50\% the following year. Purchases of labor and materials are shown along with payments made each year. The firm purchases $50 \%$ of the material it needs for a given year's production one year previous and the remaining material in the year of production. The firm pays for $70 \%$ of the material purchased in the same year as the purchase and the remaining $30 \%$ the following year. The firm purchases all labor in the same period the labor is required for production and pays its labor costs at the time of purchase. The table also shows that the firm sets aside $\$ 20,000$ for cash needed during the project's life and returns the $\$ 20,000$ to general use at the end of the project.

\begin{tabular}{|l|c|c|c|c|c|}
\hline \multirow{2}{*}{} & \multicolumn{3}{|c|}{ Year } & $\mathbf{3}$ \\
\cline { 2 - 5 } & $\mathbf{0}$ & $\mathbf{1}$ & $\mathbf{2}$ & \\
\hline Machine Purchase & $(\$ 300,000)$ & & & & \\
\hline Sales & & $\$ 200,000$ & $\$ 250,000$ & $\$ 250,000$ & $\$ 200,000$ \\
\hline Collections in period of sale (50\% of sales) & & 100,000 & 125,000 & 125,000 & 200,000 \\
\hline Collections in period after sale (50\% of sales) & & & 100,000 & 125,000 & 125,000 \\
\hline Total Collections & & $\mathbf{1 0 0 , 0 0 0}$ & $\mathbf{2 2 5 , 0 0 0}$ & $\mathbf{2 5 0 , 0 0 0}$ & $\mathbf{3 2 5 , 0 0 0}$ \\
\hline $\begin{array}{l}\text { Costs } \\
\text { Labor }\end{array}$ & & $(50,000)$ & $(62,500)$ & $(62,500)$ & $(50,000)$ \\
$\quad$ Materials & & $(50,000)$ & $(62,500)$ & $(62,500)$ & $(50,000)$ \\
\hline Purchases of materials for next period production & $(25,000)$ & $(31,250)$ & $(31,250)$ & $(25,000)$ & \\
\hline Purchases of materials for current period production & & $(25,000)$ & $(31,250)$ & $(31,250)$ & $(25,000)$ \\
\hline Total purchases of materials & $(25,000)$ & $(56,250)$ & $(62,000)$ & $(56,250)$ & $(25,000)$ \\
\hline Payments for purchases made in previous period & & $(7,500)$ & $(16,875)$ & $(18,750)$ & $(16,875)$ \\
\hline Payments for purchases made in current period & $(17,500)$ & $(39,375)$ & $(43,750)$ & $(39,375)$ & $(25,000)$ \\
\hline Total payments for materials & $(17,500)$ & $(46,875)$ & $(60,625)$ & $(58,125)$ & $(41,875)$ \\
\hline Total payments for labor & & $(50,000)$ & $(62,500)$ & $(62,500)$ & $(50,000)$ \\
\hline Total payments for labor and materials & $(\mathbf{1 7 , 5 0 0 )}$ & $\mathbf{( 9 6 , 8 7 5 )}$ & $(\mathbf{1 2 3 , 1 2 5})$ & $(\mathbf{1 2 0 , 6 2 5})$ & $(\mathbf{9 1 , 8 7 5})$ \\
\hline Cash flow from cash balance & $(20,000)$ & & & & 20,000 \\
\hline Taxes paid & & $(10,000)$ & $(20,000)$ & $(20,000)$ & $(10,000)$ \\
\hline Cash Flow & $(\mathbf{3 3 7 , 5 0 0 )}$ & $(\mathbf{6 , 8 7 5})$ & $\mathbf{8 1 , 8 7 5}$ & $\mathbf{1 0 9 , 3 7 5}$ & $\mathbf{2 4 3 , 1 2 5}$ \\
\hline
\end{tabular}

Table 5: Differences between Cash Flows from Machine Costs and

Operating Cash Flows and Cash Flows from the Cash Budget

The table shows differences between cash flow from machine cost and cash flow from the cash budget (Year 0) as well as differences between operating cash flows and cash flows from the cash budget (Years 1-4).

\begin{tabular}{|l|c|c|c|c|c|}
\hline \multirow{2}{*}{ Machine Cost } & \multicolumn{5}{|c|}{ Year } \\
\cline { 2 - 6 } & $\mathbf{0}$ & $\mathbf{1}$ & $\mathbf{2}$ & $\mathbf{3}$ & $\mathbf{4}$ \\
\hline OCF & $(\$ 300,000)$ & & & & \\
\hline Cash Flows from Cash Budget & & $\$ 90,000$ & $\$ 105,000$ & $\$ 105,000$ & $\$ 90,000$ \\
\hline Difference & $(337,500)$ & $(6,875)$ & 81,875 & 109,375 & 243,125 \\
\hline
\end{tabular}

While most texts note only that changes in working capital correspond to cash flows, the cash budget used in the teaching example shows students exactly where these changes in working capital come from and why the changes affect cash flows the way they do. For example, for Year 1, the difference between operating cash flows and net project cash flows is $\$ 96,865$. Why are the operating cash flows higher than the actual cash flows? Part of the difference comes from the fact that while $\$ 200,000$ was recorded as sales in the accrual account method (and included in operating cash flows), only $\$ 100,000$ was collected. Also, while $\$ 100,000$ was recorded as costs, not all of the costs represent current cash flow. Instead, part of the costs recorded in the accrual method actually represent raw materials purchased at time zero; another part of the recorded costs is for raw materials purchased at time one that will not be paid for until time two. Finally, raw materials purchased in Year 1 to be used for production in Year 2 were not recorded as costs. In short, the difference arises because revenues and costs recorded under the accrual accounting system do not necessarily represent actual cash flows.

To track the actual cash flow, one can determine how much cash was collected and how much was disbursed. The cash paid for labor and raw materials in Year 1 is $\$ 96,875$, while collections totaled $\$ 100,000$, for a 
difference between collections and payments for labor and materials of $\$ 3,125$. Combining this amount with the $\$ 10,000$ payment for taxes gives the actual Year 1 cash flow of negative $\$ 6,875$. In Year 2, actual collections were $\$ 225,000$. Actual payments for labor and materials were $\$ 123,125$ for a difference between collections and cash payments of $\$ 101,875$. Subtracting the $\$ 20,000$ cash paid for taxes leaves $\$ 81,875$, exactly the amount of the project cash flows for Year 2. Reconciling cash flows from the cash budget with operating cash flows from other years can be done in a similar fashion.

After reconciling the differences between operating cash flows and the actual cash flows shown in the cash budget, it remains to show why these differences also correspond to changes in working capital. Referring to Table 2 , which shows working capital levels, note that between Year 0 and Year 1, inventory increased from $\$ 25,000$ to $\$ 31,250$, which corresponds to a negative cash flow of $\$ 6,250$ since cash was used to increase the inventory level. Accounts receivable increased by $\$ 100,000$, which corresponds to a negative cash flow of $\$ 100,000$ since $\$ 100,000$ of the amount recorded as sales was not collected as cash. Accounts payable increased from $\$ 7,500$ to $\$ 16,875$, which corresponds to a positive cash flow of $\$ 9,375$ since $\$ 9,375$ of the amount recorded as costs was not paid as cash. The total of these changes is negative $\$ 96,875$, exactly the difference between operating cash flow and actual cash flow in Year 1. Between Year 1 and Year 2, inventory stayed level at $\$ 31,250$ with no effect on cash flow. Accounts receivable increased from $\$ 100,000$ to $\$ 125,000$, which corresponds to a negative cash flow of $\$ 25,000$. Accounts payable increased from $\$ 16,875$ to $\$ 18,750$, which corresponds to a positive cash flow of $\$ 1,875$. The total of these changes is negative $\$ 23,125$, exactly the difference between operating cash flow and actual cash flow in Year 2.

Using the cash budget, students can not only see that changes in levels of working capital correspond to cash flows, they can see exactly where these cash flows come from. Such an understanding will give students more confidence in forecasting project cash flows than simply automatically and unthinkingly applying the "cash flows from working capital which are the opposite of changes in working capital" algorithm can provide.

\section{Modifying the Example}

The main point of the teaching example is to show why and how changes in working capital correspond to cash flows. To make this point, it is not necessary to construct an overly difficult example. In fact, instructors may wish to keep the firm's collection, payment and purchase patterns as simple as possible while still illustrating the point that changes in working capital correspond to cash flows. One very simple example would show a threeperiod project (Year 0, Year 1, and Year 2) where the firm purchases all materials required at the beginning of the project, collects 50 percent of sales in the period of sale and collects the rest the period after the sale, and pays for 50 percent of its purchases in the period of sale and pays the rest the next period. Even this simple example will demonstrate adequately that operating cash flows differ from actual project cash flows and allow instructors to show exactly how changes in working capital (which correspond to differences in when cash is paid and received) affect cash flows. Of course, the example can also be made as realistic as possible with more complicated purchase, payment, and collection patterns.

\section{STUDENT SURVEY RESULTS}

To measure the effectiveness of the teaching example in class, 34 students in an MBA managerial finance class completed a confidential survey. The students completed the survey after reading the section of the assigned text explaining working capital and cash flows in capital budgeting and after being taught the concept using the simpler modified version of the teaching example discussed above. Students rated the effectiveness of the text in explaining the concept of working capital and cash flows in capital budgeting and the effectiveness of the teaching example, both alone and compared with one another. Table 6 shows the survey results. The percentage of students who agreed or agreed strongly that the example was effective was $79 \%$ compared to $46 \%$ of students who agreed or agreed strongly that the discussion in the text was effective. In a direct comparison, $73 \%$ of students felt the teaching example was more effective than the text discussion, while only $14 \%$ felt the text discussion was more effective than the example. Clearly, the teaching example added to students' understanding of the concept of cash flows from working capital in cash budgeting. 
Table 6: Survey Results

The table shows results of a survey of 34 MBA students in a managerial finance class regarding the effectiveness of the assigned text and the teaching example in teaching the concept of cash flows from changes in working capital in capital budgeting analysis.

\begin{tabular}{|c|c|c|c|c|c|}
\hline Question 1 & $\mathbf{A S}$ & $\mathbf{A}$ & $\mathbf{N}$ & $\mathbf{D}$ & DS \\
\hline The discussion in the text was effective & $5 \%$ & $41 \%$ & $32 \%$ & $20 \%$ & $0 \%$ \\
\hline Question 2 & $\mathbf{A S}$ & $\mathbf{A}$ & $\mathbf{N}$ & $\mathbf{D}$ & DS \\
\hline The example used in class was effective & $41 \%$ & $38 \%$ & $20 \%$ & $0 \%$ & $0 \%$ \\
\hline \multicolumn{2}{|l|}{ Question 3 } & & & & \\
\hline \multicolumn{2}{|l|}{ Compare the effectiveness of the text with the effectiveness of the example used in class } & & & & \\
\hline The text was more effective & $14 \%$ & & & & \\
\hline The example was more effective & $73 \%$ & & & & \\
\hline Both were equally effective & $8 \%$ & & & & \\
\hline Neither was effective & $2 \%$ & & & & \\
\hline
\end{tabular}

\section{CONCLUSION}

In capital budgeting analysis, cash flows from changes in working capital must be accounted for. Many finance texts simply note that changes in working capital represent cash flows, but students learning capital budgeting very often have difficulty understanding why. This paper develops a teaching example to compare operating cash flows (calculated by adding depreciation to net income) with cash flows calculated using a cash budget. The example shows that the differences between operating cash flows and the cash flows from the cash budget exactly equal the changes in working capital levels. More importantly, the example also shows exactly why changes in working capital represent cash flows. Results of a survey of MBA students indicate that the teaching example can enhance student understanding of capital budgeting.

\section{AUTHOR INFORMATION}

James A Turner, Ph.D., Weber State University, 3803 University Circle, Ogden, UT 84408. James Turner is an Assistant Professor of Finance in the Goddard School of Business and Economics at Weber State University. E-mail: JamesTurner@weber.edu

\section{REFERENCES}

1. Booth, Laurence, Sean Cleary, and Pamela Patterson Drake, 2014, Corporate Finance. John Wiley \& Sons, New York.

2. Brigham, Eugene F., and Michael C. Ehrhardt, 2011, Financial Management: Theory and Practice. SouthWestern Cengage Learning, Mason, Ohio.

3. Ross, Stephen A., Randolph W. Westerfield, Jeffrey F. Jaffe, and Bradford D. Jordan, 2011, Corporate Finance: Core Principles \& Applications. McGraw-Hill Irwin, Boston.

4. Shapiro, Alan C., 2005, Capital Budgeting and Investment Analysis. Pearson Prentice Hall, Upper Saddle River, New Jersey. 
NOTES 